\title{
SITUS PERMUKIMAN KUNO DI WAEYASEL KECAMATAN LEIHITU BARAT MALUKU TENGAH
}

\author{
Site Of Ancient Settlement in Waeyasel \\ West Leihitu District Central Maluku
}

\author{
Marlyn Salhuteru \\ Balai Arkeologi Ambon \\ Jl. Namalatu Latuhalat Ambon 97118 \\ marlynsalhuteru@ymail.com
}

\begin{abstract}
Abstrak
Situs permukiman kuno yang terdapat di dusun Waeyasel, penduduk setempat menyebutnya Kota Mulu adalah sebuah dataran di antara bukit karang yang cukup terjal. Penduduk di sekitar situs meyakini bahwa Kota Mulu adalah lokasi permukiman masyarakat Waeyasel pada masa lampau. Tim penelitian Balai Arkeologi Ambon melakukan penelitian di situs ini dengan menerapkan metode survei permukaan bertujuan untuk mendata dan mendokumentasikan sebanyak mungkin data arkeologi. Penelitian ini menghasilkan sejumlah data arkeologi yang berciri megalitik berupa dolmen, sejumlah fragmentaris keramik lokal maupun keramik asing, dan sebuah makam. Sementara dapat disimpulkan bahwa situs kota mulu adalah situs permukiman yang didalamnya juga berlangsung kegiatan sakral sesuai dengan kepercayaan penghuninya, yang dibuktikan dengan keberadaan dolmen sebagai media upacara megalitik. Sedangkan keberadaan makam pada situs ini oleh penduduk sekitar dikatakan merupakan makam dari seorang pesiar agama Islam yang menyebarkan ajaran agama di waeyasel dan sekitarnya. Beliau kemudian meninggal dan dimakamkan di lokasi ini.
\end{abstract}

Kata kunci : Kota Mulu, situs, permukiman kuno, megalitik.

\begin{abstract}
Site of ancient settlements located in the hamlet Waeyasel, the locals call it the City Mulu is a plateau in between fairly steep cliff. Residents around the site believes that the City Mulu is Waeyasel community settlements in the past. Ambon Archaeological Institute research team conducted research at this site by applying the method of surface survey aims to assess and document the archaeological data as much as possible. This study resulted in a number of archaeological data, characterized by megalithic dolmen form, a number of fragmentary local and foreign ceramics ceramics, and a tomb. While it can be concluded that the site Mulu city is the site of settlements which also takes place in accordance with the trust sacred activity occupants, as evidenced by the presence of megalithic dolmen as a media ceremony. While the existence of the tomb on this site by people around say is the tomb of a cruise Islam spread religion in Waeyasel and surrounding areas. He then died and was buried at this location.
\end{abstract}

Keywords : City Mulu, sites, ancient settlements, megalithic.

\section{PENDAHULUAN}

\section{Latar Belakang}

Latar belakang sejarah pulau Seram sebagai pulau ibu bagi manusia dan kebudayaan yang berada di wilayah Maluku memang dibuktikan dengan potensi arkeologinya yang cukup beragam. Salah satunya adalah bukti hunian ataupun situs permukiman kuno. Belwood (1996) menuliskan wilayah Sulawesi dan Kepulauan Maluku sejak dulu merupakan wilayah strategis di kawasan Pasifik, karena menjadi jembatan penghubung antara kawasan Asia dengan Kepulauan Pasifik lainnya (Belwood, 1996 dalam Soegondho, 2005:2). 
Hasil penelitian arkeologi yang dilaksanakan di wilayah Maluku memperlihatkan adanya unsur budaya memperlihatkan adanya unsur budaya
astronesia, yaitu sebuah budaya yang disebarkan oleh bangsa-bangsa berbahasa Austronesia di kawasan antara Madagaska barat hingga Easter Island (Pasifik) di belahan timur serta Formosa di sebelah utara (Belwood, 2001; ibid). Budaya ini dikenal melalui budaya batu beliung persegi, bangunan megalitik sebagai sarana pemujaan nenek moyang, serta tempayan kubur sebagai media penguburan (Geldren 1945; Duff 1970; op.cit). Di wilayah Maluku bukti budaya austronesia didominasi oleh tinggalan megalihtik berupa batu meja (dolmen, menhir) dan alat-alat batu beliung perseg (neolithik). Dengan demikian dari data arkeologi prasejarah dapat ditarik interpretas bahwa budaya Maluku merupakan wilayah persebaran pengaruh budaya austronesia. Hal ini nampaknya berkesusaian dengan pendapat para ahli yang menyebutkan asal-usul sukusuku pertama yang bermukim di wilayah Maluku (terutama Pulau Seram) berasal dari ras Austro Melanesia dan Proto Melayu. Penelitian arkelogi di wilayah Maluku, melalui temuan alat-alat batu prasejarah dan megalithik, telah memperkuat pendapat in (Handoko, 2007).

Pulau Seram merupakan sebuah pulau besar yang terdapat dalam gugusan kepulauan maluku. Pulau Seram diyakini sebagai pulau ibu bagi manusia dan kebudayaan yang hidup di seluruh kepulauan Maluku. Untuk itu Pulau seram dianggap penting dalam melakukan penelitian yang bertujuan untuk mengungkapkan sejarah dan kepurbakalaan Maluku pada umumnya.

Penelitian kepurbakalaan di Pulau Seram pertama kali dilakukan oleh penelit asing sejak puluhan tahun yang lalu. J Rodder
(1937) melakukan penelitian di wilayah Seram Barat dan menghasilkan data arkeolog berupa lukisan yang tertera pada ceruk sert dinding-dinding batu karang yang terjal di daerah Rumahsokat. Bentuk-bentuk lukisan yang dilaporkan adalah manusia, binatang melata, ikan, burung, perahu, dan cap tangan serta beberapa lukisan yang belum diketahui maknanya. Di daerah Sungai Tala Rodder menemukan lukisan-lukisan dinding dengan pola manusia, rusa, burung, perahu, lambang matahari, bentuk mata, serta sejumlah goresan dengan menggunakan warna merah dan putih yang jumlahnya hampir mancapai 100 buah (Heekeren, 1972).

Penelitian kepurbakalaan di wilayah maluku termasuk di Pulau Seram mula dilaksanakan oleh instansi pemerintah sejak tahun 1995, yakni sejak berdirinya Balai Arkeologi Ambon. Lokasi penelitian yang telah dilaksanakan di Pulau Seram antara lain adalah di Hatusua, Sahulau, Elpaputih, Taniwel, Piru, dan sebagainya. Hasil penelitian sebagian besar menghasilkan data arkeologi prasejarah. Yang menarik adalah hampir semua desa yang didatang menyimpan data arkeologi permukiman dan unsur budaya megalitik. Situs permukiman yang terdapat di wilayah Maluku umumnya biasanya terdapat di perbukitan, dan umumnya mempunyai ciri yang khas, yaitu terdapa pagar keliling atau dwala yang disebut kota baik yang masih utuh maupun yang tersisa sebagian. Ciri yang kedua adalah hampir di semua situs permukiman ditemukan hasi budaya megalitik berupa dolmen disamping data arkeologis lainnya. Untuk itu, maka pada kesempatan ini tim penelitian Bala arkeologi Ambon melaksanakan penelitian arkeologi permukiman dengan sasaran desa di pesisir selatan Pulau seram tepatnya di sekitar tanjung Sial. Yang menjadi lokasi penelitian kali ini adalah Dusun Waeyasel.

Pada umumnya manusia akan mencari dan memilih lokasi permukiman yang menyediakan beberapa hal yang dibutuhkan untuk kelangsungan hidupnya. Pada waktu manusia belum mengenal hidup menetap, ia akan selalu berpindah mencari daerah baru yang menyediakan bahan makanan apabila di daerah lamanya bahan makana mulai berkurang. Sejalan dengan berkembangnya pengetahuan manusia, maka manusia mula beralih pada cara hidup menetap. Yang dijadikan lokasi bermukim manusia pada masa ini biasanya adalah gua-gua alam maupun situs-situs terbuka di tepi pantai. maupun situs-situs terbuka di tepi pantai. Untuk memenuhi kebutuhan hidupnya beupa makanan, manusia kemudian mengenal cara bercocok tanam dan memelihara binatang. Pada masa bercocok tanam inilah, manusia kemudian mengenal tradisi pemujaan arwah leluhur atau yang dikenal dengan tradisi megalitik.

\section{Metode Penelitian}

Metode penelitian adalah langkahlangkah atau cara yang ditempuh dalam sebuah penelitian untuk dapat menjawab permasalahan yang diajukan dalam penelitian tersebut. Untuk itu, metode penelitian yang dipakai dan diharapkan dapat menjawab permasalahan penelitian kali ini adalah sebagai berikut.

Penelusuran atau studi pustaka biasanya dilakukan sebelum memulai suatu kegiatan penelitian. Penelusuran pustaka dilakukan untuk mencari berbagai informasi penting mengenai lokasi maupun objek penelitian sebelum turun langsung ke lapangan. Penelusuran pustaka dilakukan melalui laporan-laporan penelitian sebelumnya, melalui koran, majalah maupun sumber informasi tertulis lainnya. Survei permukaan dilakuakan untuk menjangkau dan merekam sebanyak mungkin data yang ditemukan di lapangan. Perekaman data survei meliputi pencatatan, pengukuran, pemotretan serta penggambaran. Teknik wawancara dilakukan untuk dapat memperoleh data lisan yang tidak didapatkan dalam survei. Teknik wawancara dilakuakn kepada beberapa informan yang dianggap mengetahui baik menyangkut sejarah maupun keterangan lainnya mengenai situs dan sumberdaya arkeologi yang terdapat pada lokasi penelitian. Selanjutnya dalam tahap pengolahan data dilakukan analisis yang mencakup:

- Analisis individu yaitu analisa terhadap temuan secara individual sehingga dapat diketahui nama benda, bahan, serta fungsinya pada masa lampau.
- Analisis himpunan yaitu suatu analisa terhadap himpunan / kelompok temuan yang ada pada situs tersebut sehingga yang ada pada situs tersebut sehingga
dapat diketahui hubungan antar temuan dapat diketahui hubungan antar te
serta fungsinya dalam himpunan.

- Analisis kontekstual yaitu suatu analisa terhadap semua temuan serta hubungannya dengan lingkungan alam sekitarnya.

- Studi banding adalah membandingkan suatu situs dengan situs-situs sejenis di lokasi lain.

\section{HASIL DAN PEMBAHASAN}

Situs permukiman di dusun Waeyase terletak di pegunungan yang cukup terjal, berjarak kurang lebih $2 \mathrm{Km}$ dari dusun Waeyasel dan dapat ditempuh dengan berjalan kaki menyususri areal perkebunan selama kira-kira 2 jam perjalanan. Situs negeri lama ini disebut "kota mulu", terletak pada ketinggian kira-kira 200 meter di atas permukaan air laut. Situs ini merupakan situs terbuka yang terletak pada sebidang tanah datar, yang luasnya diperkirakan mencapa $200 \mathrm{~m}$. Pada bagian utara dan bagian timu situs terlihat adanya pagar keliling yang terbuat dari tumpukan batu karang, setinggi $80 \mathrm{~cm}-100 \mathrm{~cm}$ dari permukaan tanah. Diduga, pada saat masih difungsikan, situs ini dikelilingi oleh pagar batu, namun karen pengaruh alam dan manusia, pagar batu tersebut hanya sebagian kecil saja yang masih tersisa dan dapat diamati sampai saat ini. D beberapa lokasi situs permukiman kuno di Maluku juga dapat dijumpai bahwa lokasi permukiman lama atau situs permukiman yang disebut kota adalah suatu lokasi yang dipagari dengan pagar batu keliling. Misalnya situs permukiman yang terdapat di Seram Barat, dan Maluku Tengah.

Sisa-sisa okupasi manusia yang masih bisa ditemukan di situs ini berupa dolmen, fragmen keramik asing dan fragmen gerabah. Lokasi sekitar situs ini masih dianggap keramat oleh masyarakat setempat. Oleh pemerintah desa, penduduk sekitar 
dilarang menebang pohon yang terdapat di sekitar situs ini.

Lokasi ditemukannya sebaran fragmen gerabah dan keramik asing diduga merupakan pusat permukiman lama yang pernah dihuni pada masa lampau. Hasil identifikasi terhadap sisa fragmentaris gerabah dan keramik asing tersebut memperlihatkan bentuk-bentuk wadah seperti piring, mangkuk, kendi, dan tempayan. Gerabah dan keramik asing merupakan benda yang dipergunakan seharihari oleh masyarakat pemukim situs Kota Mulu ini. Motif yang dapat diamati pada fragmen gerabah yang terdapat di situs Kota Mulu berupa motif geometris, garis lurus dan garis setengah lingkaran. Pola hias semacam ini diperoleh dengan melakukan teknik hias gores dan cukil.

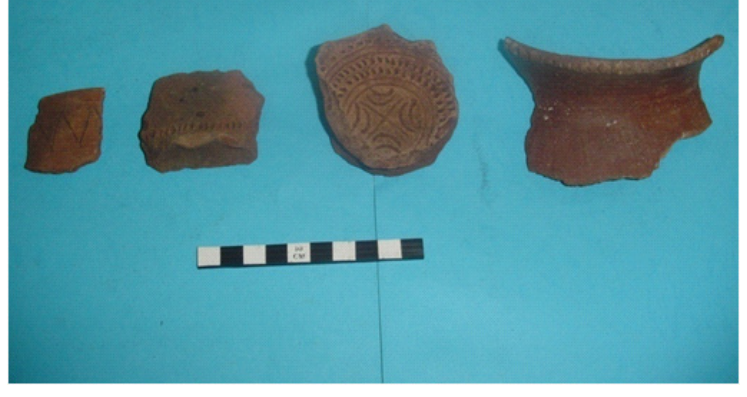

Foto 1. Gerabah di situs Kota Mulu. Dokumentasi Balar Ambon

Melihat keadaan sekitar situs, disimpulkan bahwa gerabah yang ada di situs ini bukan merupakan produksi setempat, melainkan didatangkan dari luar karena disekitar situs tidak ditemukannya sumber bahan baku yaitu tanah liat. Selain itu, gerabah bukan merupakan barang yang dipergunakan oleh masyarakat saat ini di Desa Waeyasel dan sekitarnya. Mungkin saja gerabah-gerabah tersebut merupakan hasil perdagangan barter dengan pedagang lokal maupun pedagang asing yang ditukarkan dengan komodit dari Waeyasel. Di Maluku sendiri, lokas pembuatan atau produksi gerabah tradisiona yag masih berlangsung sampai sekarang antaranya adalah di Kecamatan Saparua tepatnya di Desa Ouw dan di Kabupaten maluku Tenggara yaitu di Tanimbar Kei.

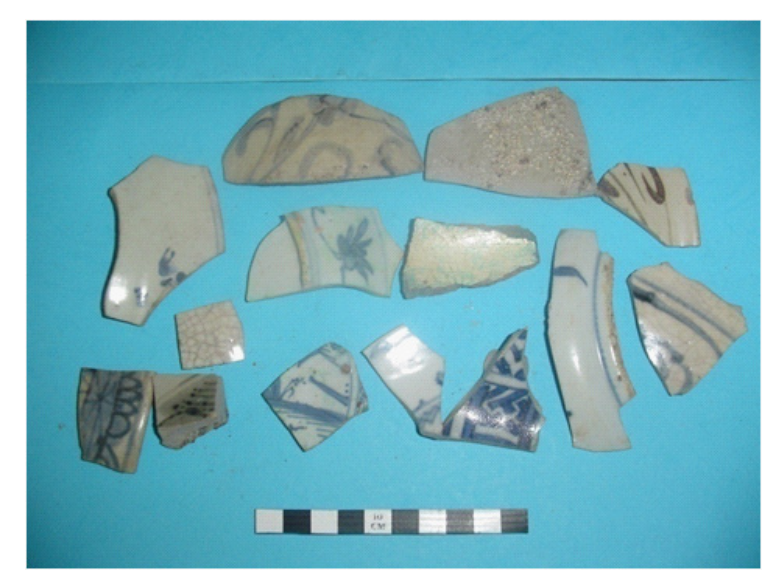

Foto 2. Fragmen keramik asing di

Dokumentasi Balar Ambon

Fragmen keramik asing yang ditemukan di situs Kota Mulu merupakan bentuk wadah berupa piring, mangkuk, dan cawan. Terbuat dari tanah liat berwarna putih, warna glasirnya adalah warna putih kebirubiruan dengan motif hias flora. Fragmen keramik yang terdapat di situs Kota Mulu merupakan keramik China yang berasal dari dinasti Ching dan Ming. Keberadaan fragmen keramik asing di situs ini membuktikan bahwa situs Kota Mulu pada masa lampau telah mempunyai hubungan perdaganagan barter dengan pedagang baik lokal maupun pedagang asing yang berlabuh di pesisir Pulau Seram dan sekitarnya.

Kurang lebih $100 \mathrm{~m}$ dari lokas sebaran fragmen gerabah dan keramik asing terdapat sebuah dolmen. Dolmen atau yang disebut penduduk setempat sebagai meja batu merupakan sebuah batu datar yang ditopang oleh empat buah batu tegak. Namun sangat disayangkan, kondisi dolmen tidak terawat, bahkan batu datarnya sudah runtuh, kecuali batu penyanggahnya. Disekitar dolmen nampak diletakan batu mengelilingi dolmen dengan jarak $50 \mathrm{~cm}$ dari posisi dolmen. Terdapat juga beberapa benda di dekat dolmen seperti botol minyak wangi, pecahan kendi dan bekas anyaman diduga merupakan wadah makanan. Benda-benda ini membuktikan bahwa dolmen di situs ini masih sering dikunjungi. Temuan di sekitar dolmen kemungkinan merupakan benda yang sengaja diletakan oleh pengunjung. Ritual seperti ini seringkali kita jumpai terjadi di situs-situs prasejarah di Maluku. Dolmen dianggap sebagai perwujudan nenek moyang yang dapat melindungi dan mendatangkan pengaruh baik bagi masyarakat. Oleh karen itu masyarakat sudah seharusnya menjaga hubungan baik dengan arwah nenek moyang yang mereka yakini itu. Salah satunya adalah dengan mengunjungi dan melakukan semacam ritual dengan menyertakan bendabenda seperti uang logam, rokok, wewangian, arak, dan sebagianya.

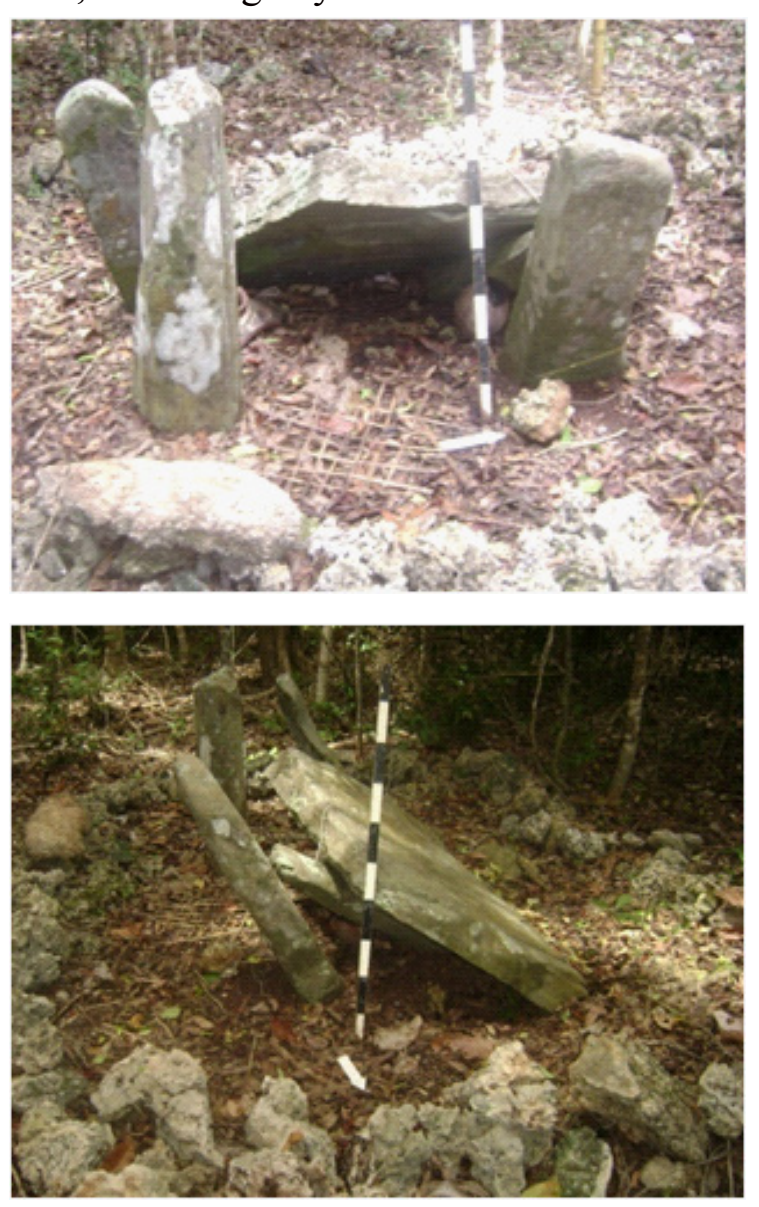

Foto 3 dan 4. Dolmen yang terdapat di situs permukiman kuno Kota Mulu

Di situs ini terdapat sebuah makam yang oleh masyarakat setempat diyakini sebagai makam para penyiar Islam. Makam yang berorientasi utara-selatan ini dikelilingi dengan tumpukkan batu karang setinggi 80 $\mathrm{cm}$. Pada bagian tengah makam diletakan sebuah menhir yang berfungsi sebagai nisan, namun menhir ini telah runtuh merapat ke tanah.. Makam ini masih dikeramatkan dan kelihatannya makam ini masih sering diziarahi oleh penduduk sekitar. Hal ini terlihat dengan adanya tinggalan berupa uang logam (koin), botol minyak wangi, rokok, dan sebagainya yang sengaja diletakan oleh peziarah.

Makam yang terdapat di situs Kota Mulu ini merupakan makam Islan apabila dilihat dari arah hadapnya, tetapi menggunakan menhir sebagai nisan. In menunjukkan adanya akulturasi budaya prasejarah dan Islam. Makam Islam yang berada dalam kompleks situs megalitik menandakan adanya keberlanjutan tradisi dar tradisi megalitik dan pemujaan arwah leluhur, walaupun pemukimnya telah mengenal agama Islam. Dengan demikian maka dapat dikatakan bahwa situs ini merupakan situs yang intensif didiami atau dimukimi sejak masa pra Islam hingga masuknya pengaruh Islam. Untuk menggambarkan dengan lebih jelas tentang sejarah penghunian situs kiranya diperlukan penelitian yang lebih mendalam.

\section{PENUTUP}

Hasil penelitian yang dilaksanakan di dusun Waeyasel menunjukkan bahwa dusun Waeyasel adalah lokasi permukiman yang telah dihuni cukup lama, walaupun untuk menjelaskan kronologi dari situs ini masih dibutuhkan proses penelitian yang panjang dan lebih intensif. Kota mulu adala sebutan penduduk sekitar menunjuk pada suatu situs permukiman yang terletak di perbukitan dalam wilayah Dusun Waeyasel. Data arkeologis yang terdapat pada situs in setidaknya dapat menjelaskan kronologi situs secara relatif. Fragmentaris keramik lokal maupun keramik asing yang ditemukan dalam area situs membuktikan fungsi situs sebagai situs permukiman, walaupun tidak atau belum ditemukannnya bekas-bekas bangunan 
hunian. Kemungkinan bangunan-bangunan tersebut terbuat dari bahan sederhana seperti kayu dan bambu sehingga sangat rapuh dan mudah hancur dan tidak dapat dikenali keberadaannya saat ini. Setidaknya, Keramik lokal dan keramik asing dalam bentuk fragmentarisnya telah menjelaskan adanya hubungan penduduk Kota Mulu dengan dunia luar, kemungkinan merupakan hasil barter penduduk setempat dengan pedagang baik pedagang lokal maupun pedagang asing. Dolmen merupakan gambaran dari kepercayaan penduduk pada masa itu. Terdapatnya dolmen dalam suatu permukiman dapat menjelaskan bahwa penduduk Kota Mulu merupakan pendukung tradisi megalitik, yang membuat dan mempergunakannya sebagai media kepercayaannya terhadap leluhur. Makam yang menunjukkan ciri makam Islam terdapat dalam area situs menunjukkan adanya keberlanjutan tradisi yaitu dari tradisi megalitik atau pra Islam hingga tradisi Islam. Nisan makam berupa sebuah batu tegak atau menhir, walaupun telah runtuh namun masih bisa diamati. Perpaduan antara unsur budaya pra Islam dan unsur budaya Islam memperlihatkan akulturasi yang menarik. Masuknya pengaruh Islam tidak serta merta mengikis budaya sebelumnya, namun semakin memperkaya. Benda-benda yang terdapat di sekitar situs baik di dekat dolmen maupun di dekat makam merupakan manifestasi penghormatan terhadap leluhur yang tidak luntur, masih tetap terjaga, dan bertahan hingga saat ini.

\section{DAFTAR PUSTAKA}

Astiti, Ni Komang Ayu, 2004, Tembikar Dari Situs Batu Berak (Kebun Tebu)dan Batu Tameng Kecamatan Sumberjaya, Kabupaten Lampung Barat, dalam Amerta edisi 23 tahun 2004, Jakarta :Kementerian Kebudayaan Dan Pariwisata Deputi Biidang Sejarah Dan Purbakala Asisten Deputi Urusan Arkeologi Nasional.

Handoko, Wuri, 2008, Laporan Penelitian di Dusun Air Papaya SBB. Balai Arkeologi Ambon

Indriastuti, Kristantina, 2010, Akulturasi Budaya Austronesia (Tinjauan pada Tempayan kubur di Wilayah Sumatera Bagian Selatan), dalam Kapata Arkeologi Vol. 6 No. 10 Juli 2010, Ambon : Balai Arkeologi Ambon 2010.

Kusumawati, Ayu, Sumba Pusat Tradisi Megalitik Berlanjut Di Indonesia Timur dalam Forum Arkeologi No. 1 April 2010, Editor: Drs. I Nyoman Wardi, M.Si

Salhuteru, Marlyn, 2007, Persebaran Dolmen di Saparua maluku Tengah, Balai Arkeologi Ambon.

Wikipedia, Ensiklopedia Bebas. 